\title{
Lifetime assessment of solid-state hybrid supercapacitors based on cotton fabric electrodes
}

\author{
A.J. Paleo ${ }^{\text {a, }}$, P. Staiti ${ }^{\text {b }}$, A.M. Rocha ${ }^{\text {a }}$, G. Squadrito ${ }^{\text {b }}$, F. Lufrano ${ }^{\text {b, *** }}$ \\ a 2 C2T - Centro de Ciência e Tecnologia Têxtil, Universidade do Minho, Campus de Azurém, 4800-058, Guimarães, Portugal \\ " CNR-ITAE, Istituto di Tecnologie Avanzate per l'Energia "Nicola Giordano", 98126, S. Lucia, Messina, Italy
}

\section{H I G H L I G H T S}

- Hybrid cotton fabric electrodes with $\mathrm{MnO}_{2}$ and AC by easy processes were developed.

- A new assessing method for long-term durability under harsh conditions is analysed.

- The use of Aquivion as solid-state electrolyte in SCs is introduced for first time.

- The hybrid solid-state supercapacitors worked with success in a high voltage range.

- The supercapacitors showed low self-discharge rates and good specific capacitances.

\section{A R T I C L E I N F O}

\section{Keywords:}

Carbon nanofiber

Manganese oxide

Solid-state electrolyte

Hybrid supercapacitor

\begin{abstract}
A B S T R A C T
Electrodes based on activated carbon and manganese oxide coated on a cotton woven fabric were developed and investigated. The electrodes were then assembled with two polymer electrolyte membranes, Nafion ${ }^{\circledR} 115$ and Aquivion ${ }^{\circledR E 87-05 S}$, and two different supercapacitors were produced with specific capacitances and energy densities of 130 and $132 \mathrm{~F} \mathrm{~g}^{-1}$, and 11.5 and $11.7 \mathrm{Wh} \mathrm{kg}^{-1}$, respectively. Furthermore, a new durability methodology, which combines galvanostatic charge/discharge cycles together with potentiostatic floating conditions, was used to get insight into their electrochemical performance under stringent conditions. The supercapacitor assembled with Nafion ${ }^{\circledR} 115$ electrolyte worked successfully for $10 \mathrm{k}$ cycles and $140 \mathrm{~h}$ under a constant voltage of $1.6 \mathrm{~V}$ (floating condition), whereas the supercapacitor assembled with Aquivion ${ }^{\circledR E 87-05 S ~ e l e c t r o l y t e ~ w o r k e d ~}$ successfully for more than $15 \mathrm{k}$ cycles and $210 \mathrm{~h}$, without any appreciable degradation of their electrochemical properties. In summary, hybrid solid-state supercapacitors based on electrodes produced by simple methodologies and low-cost materials, and with long durability performance under very harsh conditions were developed and analysed for their potential utilization as flexible energy storage devices.
\end{abstract}

\section{Introduction}

At present, batteries and electrochemical capacitors are becoming of primary importance as power supplies of portable electronic systems. However, these devices are rigid and have limited usability in terms of mechanical stability upon bending or stretching for wearable electronics. In this respect, textile fabrics, which are thin flexible sheets of interlaced yarns produced by different technologies such as weaving, knitting, and braiding have additional advantages over other materials owing to their mechanical strength, flexibility properties and absorption and desorption ability (for absorbing and releasing of ions in the solvent)
[1], and therefore, flexible energy storage devices based on textile fabrics, particularly oriented towards the production of supercapacitors (SCs), are a viable alternative to overcome those limitations because of their quick charge-discharge capability, long life and safety. It is generally accepted that energy in SCs is electrostatically stored by accumulated charges on the electrode surface, and electrolyte ions with counterbalancing charge on the electrolyte side, which is denominated as electric double layer capacitance (EDLC) [2]. However, the fabrication of scalable, lightweight and durable textile-based SCs possessing a combination of high capacitance with high power and energy density is still a significant challenge [3], and fabric-based electrodes with high

\footnotetext{
* Corresponding author.

$* *$ Corresponding author.

E-mail addresses: ajpaleovieito@2c2t.uminho.pt (A.J. Paleo), lufrano@itae.cnr.it (F. Lufrano).
} 
electronic conductivity thanks to the incorporation of carbon nanostructures such as carbon nanotubes (CNT) [4], graphene [5,6], and/or a combination of them [7] by different methodologies [8], have been recently proposed for the design of SCs. Nevertheless, the electrochemical properties of the above mentioned carbon nanostructures are still limited. In this regard, it is well known that charge storage can be increased in supercapacitors with pseudocapacitance, i. e. fast surface redox reactions, which occur at or near the surface of carbon materials, conducting polymers [9] and transition metal oxides [10]. Consequently, activated carbon (AC) with mesoporous structures [11] together with pseudocapacitive metal oxides such as manganese oxides $\left(\mathrm{MnO}_{\mathrm{x}}\right)$ [12], are frequently added to the fabric-based electrodes to enhance their electrochemical properties. On the other hand, cotton-based textiles are drawing strong attention among natural fiber textile fabrics to act as wearable platform for textile supercapacitors [13, 14]. The current research in the development of textile supercapacitors can be separated into two main lines of investigation, bottom-up and top-down. In the bottom-up approach, natural or synthetic fibers are transformed into electrode fibers by different methodologies, and so they can be interlaced in a subsequent step to produce energy storage devices $[15,16]$. On the contrary, in the top-down approach already final product textile fabrics are transformed into energy storage devices. The first work reporting this type of top-down approach with cotton fabric has been conducted by Yi Cui research group in 2010 [17]. In that work, dip-coated CNT cotton fabric electrodes electrodeposited with $\mathrm{MnO}_{2}$ were studied for producing hybrid SCs with excellent cycling stability and specific capacitances of around $125 \mathrm{~F} \mathrm{~g}^{-1}$ in the working voltage range of $0.8 \mathrm{~V}$. The use of cotton fabric as the starting material of the electrodes for SCs have been also investigated in some other relevant works. For instance, polypyrrole (PPy) nanorods were deposited on cotton fabrics, and the obtained fabrics could be directly used as supercapacitor electrodes, with a maximum specific capacitance of $325 \mathrm{~F} \mathrm{~g}^{-1}$ in the working voltage range of $0.8 \mathrm{~V}$, and an energy density of 24.7 $\mathrm{Wh} \mathrm{kg}^{-1}$ [18]. In another recent work, electrodes were produced with multiwall carbon nanotubes (MWCNT) and reduced graphene oxide (rGO) deposited by vacuum filtration on nickel coated cotton fabric. The electrodes were then assembled with a cotton fabric separator in $5 \mathrm{M} \mathrm{LiCl}$ aqueous electrolyte solution. The final SCs achieved a specific capacitance of $262 \mathrm{~F} \mathrm{~g}^{-1}$ at $0.84 \mathrm{~A} \mathrm{~g}^{-1}$ in the working voltage range of $0.8 \mathrm{~V}$, and an unexpected increment of $18 \%$ in their specific capacitance after $10 \mathrm{~K}$ cycles [19]. On the other hand, the good performance of SCs depends also of the type and conductivity of the electrolyte used, which has the double function of working as separator between the electrodes and transport of electrolyte ions when it has the form of gel or polymer $[20,21]$. Since aqueous electrolytes show practical disadvantages in wearable SC devices due to liquid leakage, there is an increasing interest in replacing them with polymer/gel electrolytes [22]. For instance, a solid-state flexible and asymmetric supercapacitor with PVA/LiCl gel, $\mathrm{MnO}_{2}$ nanowires and $\mathrm{Fe}_{2} \mathrm{O}_{3}$ nanotubes grown on carbon fabric electrodes, with $91.3 \mathrm{~F} \mathrm{~g}^{-1}\left(2 \mathrm{~mA} \mathrm{~cm}^{-2}\right)$ in the working voltage window of $1.6 \mathrm{~V}$, a capacitance retention of $95.2 \%$ after $3 \mathrm{~K}$ cycles, and values of resistances between 3.9 and $7.6 \Omega \mathrm{cm}^{2}$ during cycling stability test, was already reported [23]. In another work, SCs assembled with electrodes of $\mathrm{NiCo}_{2} \mathrm{O}_{4} @ \mathrm{NiCo}_{2} \mathrm{O}_{4}$ core/shell nanostructures grown on cotton activated carbon textiles and PVA/KOH, achieved a specific capacitance of $60 \mathrm{~F} \mathrm{~g}^{-1}\left(100 \mathrm{~mA} \mathrm{~cm}{ }^{-2}\right)$ in the working voltage of $1.6 \mathrm{~V}$, a resistance of around $1.5 \Omega \mathrm{cm}^{2}$, and capacitance retention of $100 \%$ after $1 \mathrm{k}$ cycles [14]. It was also recently reported the use of large-area flexible electrodes based on a polyester textile, $\mathrm{rGO}$ and PANI, and $\mathrm{PVA} / \mathrm{H}_{3} \mathrm{PO}_{4}$ as gel electrolyte, to assemble a SC with $152 \mathrm{~F} \mathrm{~g}^{-1}\left(0.5 \mathrm{~mA} \mathrm{~cm}^{-2}\right)$ in the voltage window of $0.8 \mathrm{~V}$, and retention of $85.9 \%$ after $1 \mathrm{k}$ cycles [24]. However, the PVA based solid electrolytes used in the above referenced works present also some relevant unresolved issues such as their high resistivity, the difficulty of controlling with precision their thickness during the fabrication of the SC, which can worsen the adhesion between electrode and electrolyte, and the selection of appropriate current collectors to avoid corrosion when using alkali or acid electrolytes. Furthermore, PVA based gel electrolytes in acidic and alkaline environments cannot be used with $\mathrm{MnO}_{2}$ based electrodes because of the poor chemical stability of $\mathrm{MnO}_{2}$, and they cannot achieve voltage windows above $1.23 \mathrm{~V}$ (vs NHE) because of the water decomposition, which causes very high self-discharge rate. It is in this context that we have selected the perfluorosulfonate (PFSA) Nafion ${ }^{\circledR} 115$ and Aquivion ${ }^{\circledR} E$ 87-05S membranes as solid polymer electrolytes for the design and fabrication of our SCs because of their high ionic conductivities, even as cation exchange membranes in sodium form (i.e. $\mathrm{Na}^{+}$) at $\mathrm{pH} \approx 7$, wide voltage window stability (i.e. $1.6 \mathrm{~V}$ ), controlled thickness, outstanding mechanical strength, and low self-discharge rate [25]. These polymer electrolytes are currently employed in polymer electrolyte membranes (PEMFCs) and direct alcohol (DAFCs) fuel cells because of the outstanding properties above numbered [26]. Some initial interesting characteristics of Nafion ${ }^{\circledR} 115$ electrolyte were already discussed in our previous work, where asymmetric SCs based on $\mathrm{AC} / \mathrm{MnO}_{2}$ deposited onto dip-coated carbon nanofiber cotton fabric electrodes were designed, fabricated and analyzed [27]. In the present work, we extend the application of PFSA polymer electrolytes and optimize the preparation in a single-step of $\mathrm{MnO}_{2}$ and AC cotton fabric electrodes for the fabrication of two asymmetric solid-state SCs with Nafion ${ }^{\circledR} 115$ and Aquivion ${ }^{\circledR E 87-05 S ~ e l e c t r o l y t e ~ m e m b r a n e s ~(T a b l e ~ 1) . ~ F u r t h e r m o r e, ~ a ~}$ new practical test procedure for the long-term durability assessment of asymmetric and hybrid SCs under stringent conditions, which include cycles with the combination of galvanostatic charge/discharge (G-CD) and potentiostatic floating conditions, is analysed and discussed. As far as the authors are aware, this is the first work that reports the study of a SC with the Aquivion E87-05S solid polymer electrolyte, and the lifetime assessment of solid-state SCs by using this new type of accelerated stress test method.

\section{Experimental section}

\subsection{Materials}

$100 \%$ cotton woven fabric with $14.9 \times 20.2$ warp $\mathrm{x}$ weft yarn linear density (tex) and $0.26 \mathrm{~mm}$ thickness at 18 Pa provided by a local company, was used without any type of pre-treatment as base-substrate of the electrodes. A combination of activated carbon (AC) Norit A Supra Eur with a specific surface area of $1500 \mathrm{~m}^{2} \mathrm{~g}^{-1}$, vapour grown carbon nanofibers (CNF) Pyrograf III PR 24 LHT XT with diameters of around $100 \mathrm{~nm}$ and lengths ranging from 50 to $100 \mu \mathrm{m}$, carbon black (CB) Shawinigan acetylene black, and dry powder manganese oxide $\left(\mathrm{MnO}_{2}\right)$ prepared by a simple co-precipitation method based on chemical reaction in aqueous solution [28], were used for producing the corresponding active layers with conducting and electrochemical properties. Nafion ${ }^{\circledR} 115$ DuPont and Aquivion ${ }^{\circledR}$ E87-05S with a thickness of 125 and $50 \mu \mathrm{m}$, and equivalent weight (EW) of 1100 and $865 \mathrm{~g} \mathrm{~mol}^{-1}$, respectively, were employed as polymer electrolyte membranes. All the other materials used in this work were purchased from Sigma-Aldrich and used without further purification.

\subsection{Preparation of electrodes and supercapacitors}

Two different types of electrically conducting and hybrid composite electrodes based on $\mathrm{MnO}_{2}$ (positive electrode) and AC (negative electrode) were produced. The $\mathrm{MnO}_{2}$ based electrodes were prepared by spreading onto the cotton fabric samples a slurry composed of: $70 \mathrm{wt} \%$ of $\mathrm{MnO}_{2}, 10 \mathrm{wt} \%$ of $\mathrm{CB}, 10 \mathrm{wt} \%$ of $\mathrm{CNF}, 10 \mathrm{wt} \%$ of poly(vinylidene fluoride) (PVDF) binder and N,N dimethylacetamide (DMAc) solvent, whereas the composition for the AC based electrodes was: $80 \mathrm{wt} \%$ of AC, $10 \mathrm{wt} \%$ of CNF, $10 \mathrm{wt} \%$ of PVDF and DMAc. All the electrodes were dried first at $70^{\circ} \mathrm{C}$ for $24 \mathrm{~h}$, and then a further heat treatment, which involved $1 \mathrm{~h}$ at $120^{\circ} \mathrm{C}$ and $20 \mathrm{~min}$ at $160^{\circ} \mathrm{C}$, was carried out to improve their mechanical strength. At the end, all the electrodes were hot- 
Table 1

Description of electrodes and final solid-state supercapacitor compositions.

\begin{tabular}{|c|c|c|c|c|c|}
\hline \multirow[t]{2}{*}{ Supercapacitor name } & \multicolumn{2}{|c|}{ Positive electrode } & \multicolumn{2}{|c|}{ Negative electrode } & \multirow[t]{2}{*}{ Electrolyte } \\
\hline & Composition (wt\%) & Thickness/Active Mass & Composition (wt\%) & Thickness/Active Mass & \\
\hline $\begin{array}{l}\text { Cotton@Nafion } \\
\text { Cotton@Aquivion }\end{array}$ & $\begin{array}{c}\mathrm{MnO}_{2}(70 \%), \\
\mathrm{CB}(10 \%), \\
\text { CNF }(10 \%), \\
\text { PVDF }(10 \%)\end{array}$ & $150 \mu \mathrm{m} / 2.15 \mathrm{mg} \mathrm{cm}^{-2}$ & $\begin{array}{l}\text { AC ( } 80 \%), \\
\text { CNF }(10 \%), \\
\text { PVDF }(10 \%)\end{array}$ & $175 \mu \mathrm{m} / 2.56 \mathrm{mg} \mathrm{cm}^{-2}$ & $\begin{array}{c}\text { Nafion }^{\circledR} 115 \\
\text { Aquivion }{ }^{\circledR} \text { E87-05S }\end{array}$ \\
\hline
\end{tabular}

pressed at $160{ }^{\circ} \mathrm{C}$ and 40 bar during $10 \mathrm{~min}$ with the aim of increasing their electrical conductivity, and a positive to negative electrode mass ratio of 0.84 was achieved. The electrodes were then cut in circular shapes of $2 \mathrm{~cm}^{2}$, whereas the Nafion ${ }^{\circledR} 115$ and Aquivion ${ }^{\circledR E} 87-05 S$ membranes were cut slightly larger than $2 \mathrm{~cm}^{2}$ (around $2.5 \mathrm{~cm}^{2}$ ) to prevent lateral electrical short circuits. The SCs were assembled with the Nafion ${ }^{\circledR} 115$ and Aquivion ${ }^{\circledR E} 87-05 S$ membranes and two different types of SCs, named as Cotton@Nafion and Cotton@Aquivion, were produced. The electrodes were impregnated with $1 \mathrm{M} \mathrm{Na}_{2} \mathrm{SO}_{4}$ solution, whereas the Nafion ${ }^{\circledR} 115$ and Aquivion ${ }^{\circledR E} 87-05 S$ membranes were exchanged in $\mathrm{Na}^{+}$form by immersion for $18 \mathrm{~h}$ in $1 \mathrm{M} \mathrm{Na}_{2} \mathrm{SO}_{4}$ solution under slow stirring, before assembling. Further specific details of the electrodes are shown in Table 1.

\subsection{Materials characterization}

Morphological analysis of the as-prepared electrodes (fresh electrodes) and the aged electrodes was performed in an Ultra-high resolution Field Emission Gun Scanning Electron Microscopy (FEG-SEM), FEI Company. The aged electrodes were dried at room temperature for some days, and then cut in small samples of about $0.5 \mathrm{~cm}^{2}$, which were fixed to the SEM sample holder by a conductive tape. The samples were gold coated with a thin film (about $20 \mathrm{~nm}$ ) in a cold sputter coater. The SEM analyses were carried out at $5 \mathrm{kV}$ and $20 \mathrm{kV}$ of accelerating voltage and at different magnifications by scanning the whole area of each sample. Energy dispersion of emitted x-ray (at $20 \mathrm{kV}$ ) was used to verify the uniformity in the composition of the different samples.

X-ray photoelectron spectroscopy (XPS) of cotton based fresh and aged electrodes was recorded by a Physical Electronics (PHI) 5800-01 spectrometer. Each spectrum was obtained by using pass energies of $58.7 \mathrm{eV}$, for the elemental analysis, and $11.75 \mathrm{eV}$ for the determination of the oxidation states and chemical compositions. A scan analysis was carried out for producing a survey spectrum ranging from $0 \mathrm{eV}$ to $1200 \mathrm{eV}$, which was used to determine the elemental surface composition. High-resolution scans were also carried out for Mn 2p, Mn 2s, C 1s and $\mathrm{O} 1 \mathrm{~s}$ to complete the surface analysis of electrodes. Different samples based on AC (negative electrodes) and $\mathrm{MnO}_{2}$ (positive electrodes) were calibrated with $\mathrm{C} 1 \mathrm{~s}(284.6 \mathrm{eV})$ peak. The areas of peaks were estimated by calculating the integral of each peak after subtracting the background noise and fitting the experimental peaks by the Gaussian function.

\subsection{Electrochemical characterization}

The supercapacitors with $2 \mathrm{~cm}^{2}$ circular-shape two-electrodes were investigated in a titanium cell connected to Autolab/Metrohm PGSTAT 302/FRA2 (Eco Chemie, Netherlands) potentiostat-galvanostat electrochemical workstation. The cyclic voltammetry (CV) tests were carried out in potentiodynamic mode at different voltage sweep rates $(5,10,50$ and $100 \mathrm{mV} \mathrm{s}^{-1}$ ) and voltage ranges from 0 to $+1.6 \mathrm{~V}$ and vice versa. The galvanostatic charge/discharge tests (G-CD) were carried out in the same voltage range $(0$ to $+1.6 \mathrm{~V})$ and at constant currents of $\pm 0.2, \pm 0.5$, \pm 1 and $\pm 2 \mathrm{~A} \mathrm{~g}^{-1}$. The electrochemical impedance spectroscopy tests (EIS) were performed at open circuit voltage (OCV), with voltage sine wave amplitude of $10 \mathrm{mV}$, and frequencies from $1 \mathrm{mHz}$ to $500 \mathrm{kHz}$ by using the PGSTAT 302 potentiostat equipped with the FRA2 module.

\section{Results and discussion}

\subsection{Morphology and structure of fresh electrodes}

The scanning electron microscopy images of composite electrode samples before electrochemical tests (fresh electrodes) are shown in Fig. 1. The positive electrode (Fig. 1a) is composed of spherical $\mathrm{MnO}_{2}$ nanoparticles, carbon black particles with irregular shapes and large sizes, and carbon nanofibers. All these particles and nanofibers were coated successfully on the woven cotton fabric. The $\mathrm{MnO}_{2}$ nanoparticles appear uniformly distributed, while CB particles showed larger agglomerates with micrometric sizes. CNF have the main function of connecting the $\mathrm{MnO}_{2}$ and $\mathrm{CB}$ particles, thus creating the necessary conductive paths for electronic transport. The negative electrode (Fig. 1b) showed a non-uniform distribution of AC particles in the micrometric scale range with some entangled CNF. The electronic conduction paths are also ensured by the contacts between AC particles and CNF. Overall, these fresh electrodes coupled with the sodium exchanged PFSA membranes allowed the production of solid-state SCs with excellent electrochemical characteristics.

X-ray photoelectron spectroscopy was also performed to evaluate the surface chemical composition of the fresh electrodes, and the results are shown in Fig. 1c. The full survey-scan spectrum of the positive electrode (Fig. 1c red line) shows that it is composed of four main elements: $\mathrm{Mn}, \mathrm{O}$, $\mathrm{C}$ and $\mathrm{F}$. The fluorine comes from the PVDF inert binder and hence it is not further considered. The two peaks at $642 \mathrm{eV}\left(\mathrm{Mn} \mathrm{2} \mathrm{p}_{3 / 2}\right)$ and $653.8 \mathrm{eV}\left(\mathrm{Mn} 2 \mathrm{p}_{1 / 2}\right)$, with an energy separation of $11.8 \mathrm{eV}$, showed that $\mathrm{Mn}^{4+}$ is the prevailing species on the surface $[29,30]$. The C 1 s peak at $284.6 \mathrm{eV}$ is due to the $\mathrm{CB}$ particles and the CNF, while the $\mathrm{O} 1 \mathrm{~s}$ peak at $631.5 \mathrm{eV}$ has its origin in the oxygen provided by the Mn oxides and surface oxygenated groups of the carbon materials. The whole survey spectrum of the negative fresh electrode (Fig. 1c blue line) shows only the presence of $\mathrm{C}, \mathrm{O}$ and $\mathrm{F}$ elements. Further XPS examination comparing the fresh and the aged electrodes will be discussed in the later sections.

\subsection{Electrochemical analysis at initial conditions}

The electrochemical analyses of both SCs at initial conditions obtained by CV at different voltage sweep rates from 5 to $100 \mathrm{mV} \mathrm{s}^{-1}$ are plotted in Fig. 2a and c. The current density and specific capacitance were calculated from the sum of active masses from both electrodes, ( $4.30 \mathrm{mg}$ from $\mathrm{MnO}_{2}$ and $5.12 \mathrm{mg}$ from $\mathrm{AC}$ ). The original values of the current (I) in the voltammograms were converted in specific capacitance (Cs) per one electrode mass by using the equation $\mathrm{C}\left(\mathrm{F} \mathrm{g}^{-1}\right)=4 \mathrm{x}[\mathrm{I}(\mathrm{A}) /$ $\left.\mathrm{dV} / \mathrm{dt}\left(\mathrm{V} \mathrm{s}^{-1}\right)\right] /[$ mass active materials of capacitor $(\mathrm{g})]$; where $\mathrm{dV} / \mathrm{dt}$ is the scan rate. The Cotton@Nafion SC shows slightly higher capacitance than the Cotton@Aquivion SC. In particular, the Cotton@Nafion SC showed specific capacitances close to $100 \mathrm{~F} \mathrm{~g}^{-1}$ and nearly rectangular shapes in the whole range of voltage scan rates. The quasi-rectangular shapes observed in Fig. 2a-c show a high stability at operating voltage of $1.6 \mathrm{~V}$, which is an important finding because it demonstrates the absence of evident oxygen (OER) and hydrogen (HER) evolution reactions in the electrodes [31,32]. In fact, the operation voltage of $1.6 \mathrm{~V}$ in both SCs exceeds the thermodynamic potential window of water decomposition (e.g. $1.23 \mathrm{~V}$, vs NHE) at room temperature. The 


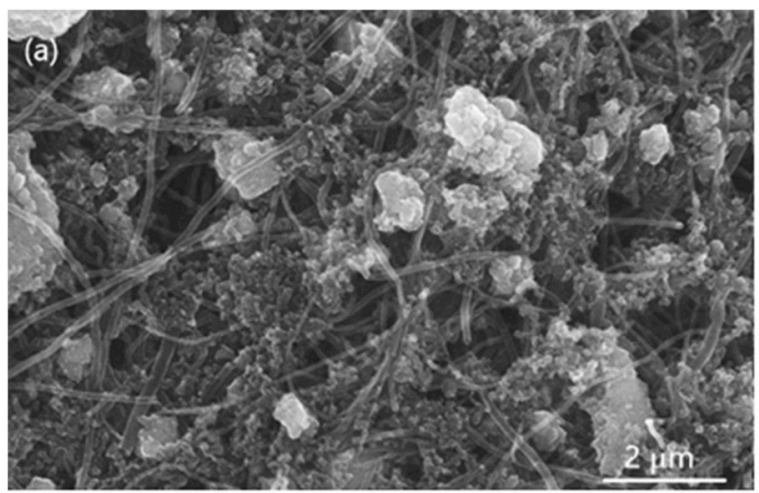

(c)

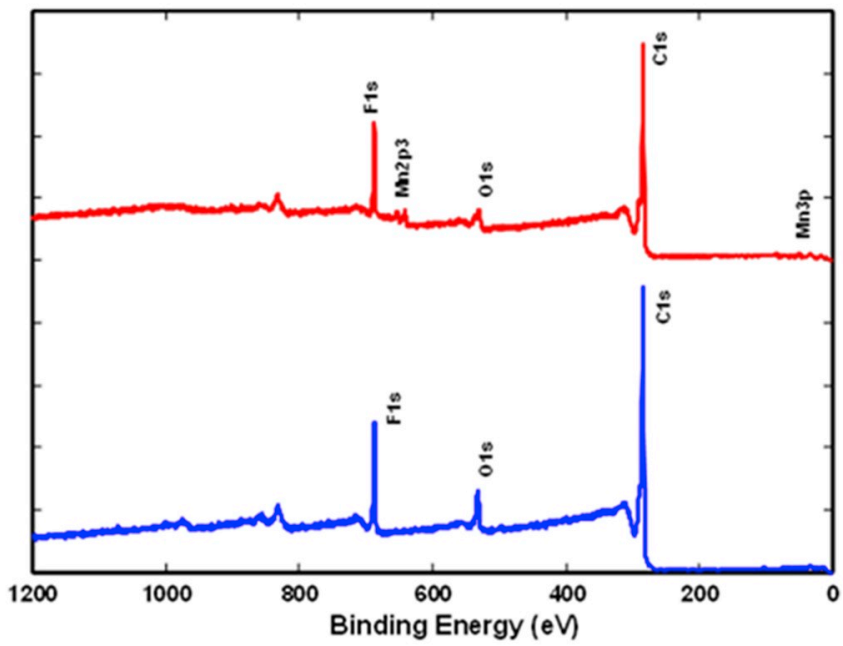

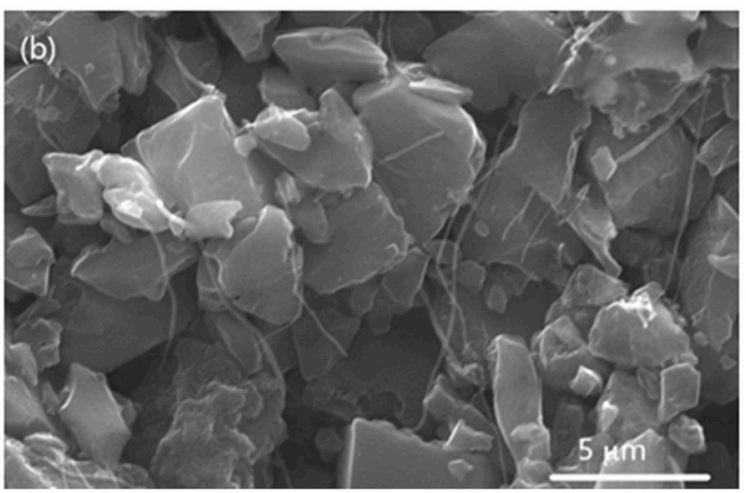

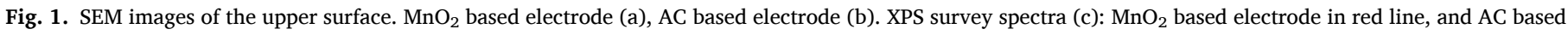
electrode in blue line. (For interpretation of the references to colour in this figure legend, the reader is referred to the Web version of this article.)

voltammograms of the Cotton@Aquivion SC showed less perfect rectangular shapes in the same voltage range, probably due to its higher distributed ionic resistances, as it is confirmed by the EIS analysis (Fig. 2e). Despite the presence of $\mathrm{MnO}_{2}$ in their positive electrodes, there is no any evidence of Faradaic processes in both SCs at the initial conditions, which can be explained because of those processes happen very fast in the whole cell $[33,34]$. In general, both SCs show in their voltammograms the quasi-rectangular shapes typically observed in electrodes with the electrical double layer capacitance (EDLC) behaviour $[27,35]$, even at the highest scan rates of $100 \mathrm{mV} \mathrm{s}^{-1}$. Fig. $2 \mathrm{~b}$ and d show the G-CD curves of Cotton@Nafion and Cotton@Aquivion SCs in the voltage range from 0 to $+1.6 \mathrm{~V}$. We observed a retention in capacitive performances of around $75 \%$ and $70 \%$ in supercapacitors with Nafion and Aquivion, respectively, when current increased from 0.2 to $2 \mathrm{~A} \mathrm{~g}^{-1}$ in G-CD tests. This is an expected result if we consider that pseudocapacitive processes, which involve a fast transfer of electrons on the surface of $\mathrm{MnO}_{2}$, are occurring [36]. Both SCs show high columbic efficiency and triangular shapes with low voltage drops (iR drop) occurring during the current inversion, associated with the over potential caused by the charge redistribution through the electrodes [37]. In summary, a similar to EDLC behaviour with low electrical resistivity and excellent capacitance is confirmed in both SCs from the analyses of their voltammograms and G-CD curves at initial conditions, which practically emulate the behaviour of electrostatic capacitors but with much higher capacitances (e. g. $>100 \mathrm{~F} \mathrm{~g}^{-1}$ ).

The Nyquist plots of both SCs at initial conditions are reported in Fig. 2e. The inset shows the high frequency region. The plots are very similar at high and very low frequency, while they show differences at intermediate frequencies where the more resistive character of Aquivion is evident. The high frequency semicircles observed in both supercapacitors were fitted by $R_{S}\left(R_{C T} C_{P E}\right)$ equivalent circuit, in which $R_{S}$ is the electrolyte resistance, $R_{C T}$ is the charge transfer resistance and $C_{P E}$ or $\mathrm{Q}$ is the constant phase element, defined as the circuit element to be used in EIS analysis when the electrodes have some roughness and high porosity [38], and a non-ideal behavior of the electric double layer have to be considered. Values of $R_{S}$ equal to 0.82 and $0.78 \Omega \mathrm{cm}^{2}$ have been calculated for Cotton@Nafion and Cotton@Aquivion SC, respectively, which evidence very low resistivities of both Nafion ${ }^{\circledR} 115$ and Aquivion ${ }^{\circledR} E 87-05 S$ membranes and fast charge propagation through electrodes (see inset of Fig. 2e). Furthermore, the Cotton@Nafion SC $\left(\mathrm{R}_{\mathrm{CT}}=2.6 \Omega \mathrm{cm}^{2}\right)$ exhibits interfacial resistances with lower radius than the Cotton@Aquivion SC $\left(\mathrm{R}_{\mathrm{CT}}=3.9 \Omega \mathrm{cm}^{2}\right)$. This latter supercapacitor also shows higher distributed resistances in the middle frequency range $(\mathrm{Hz})$, while the differences between the impedances of both SCs are less pronounced at low frequencies $(\mathrm{mHz})$, and finally the results overlap near to $1 \mathrm{mHz}$.

\subsection{Lifetime analysis under accelerated stress test}

The electrochemical characterizations of both hybrid solid-state SCs in a neutral aqueous system at initial conditions have shown high specific capacitances and low resistivities in a wide voltage window of $1.6 \mathrm{~V}$, as it was discussed in the previous section. On the other hand, we propose a different methodology for the long-term durability assessment of our supercapacitors. This test-method allows monitoring the ageing behaviour of SCs through a combined procedure of cycling and floating method, which can simulate better their lifetime and state-of-health $(\mathrm{SoH})$ under stringent environments. Specifically, the SCs are subjected to G-CD sequences consisting of an initial galvanostatic charge phase at $2 \mathrm{Ag}^{-1}$, a potentiostatic phase for $50 \mathrm{~s}$ at constant voltage of $1.6 \mathrm{~V}$ (floating condition), and a final galvanostatic discharge phase at $-2 \mathrm{~A} \mathrm{~g}^{-1}$, as it is shown in Fig. 3. Though, the floating methodology was already proposed for testing the stability of non-aqueous $[39,40]$ and aqueous [41] based supercapacitors, this combination of cycling and floating is presented for the first time with this study. This methodology is repeated up to $15 \mathrm{k}$ cycles during which the ageing behaviour was 

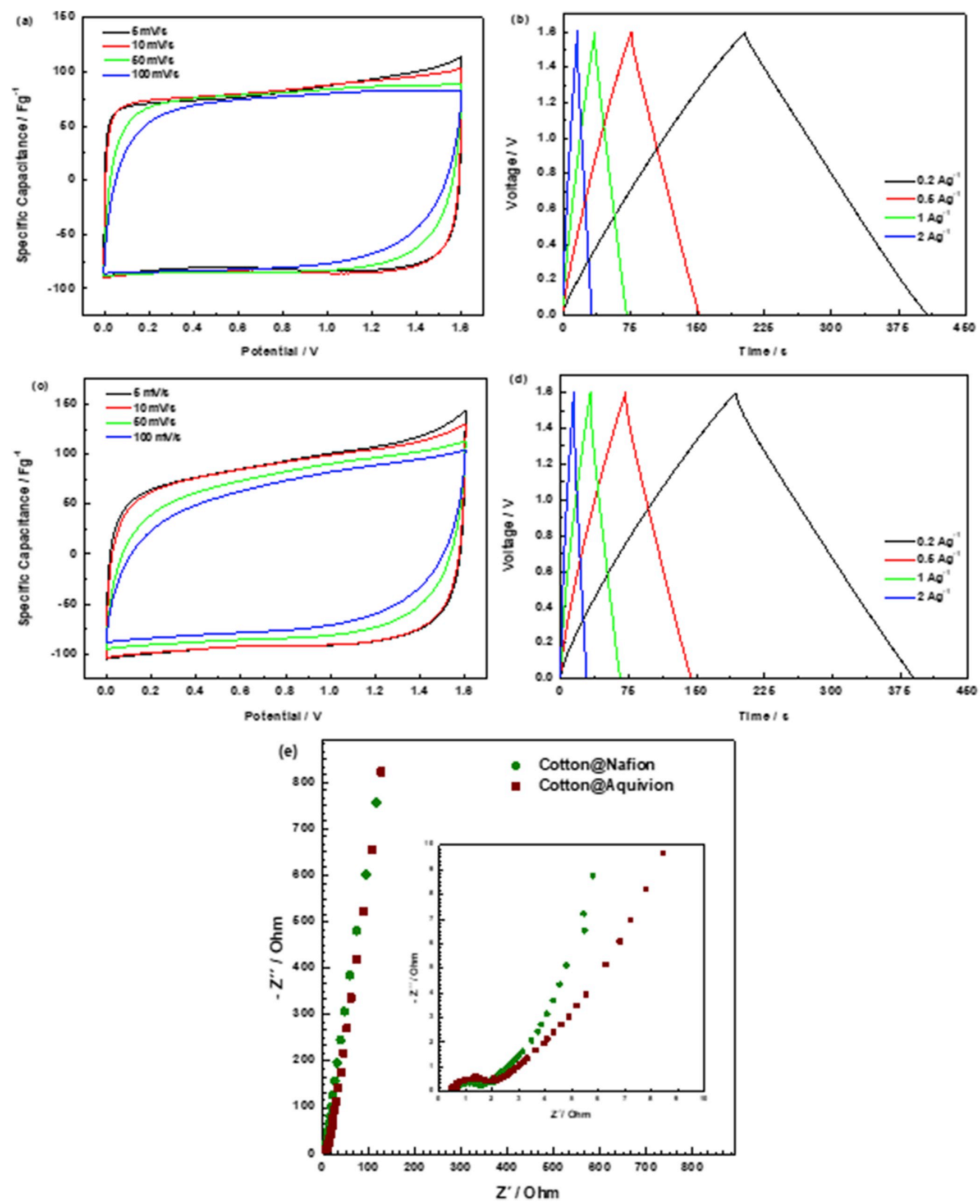

Fig. 2. Specific capacitance versus cell voltage at scan rates from $5 \mathrm{mV} \mathrm{s}^{-1}$ to $100 \mathrm{mV} \mathrm{s}^{-1}$, and G-CD at current densities from $0.2 \mathrm{Ag}^{-1}$ to $2 \mathrm{Ag}^{-1}$. Voltammograms (a) and G-CD (b) of Cotton@Nafion SC. Voltammograms (c) and G-CD (d) of Cotton@Aquivion SC. Nyquist plots of the two hybrid SCs at initial conditions (e). 


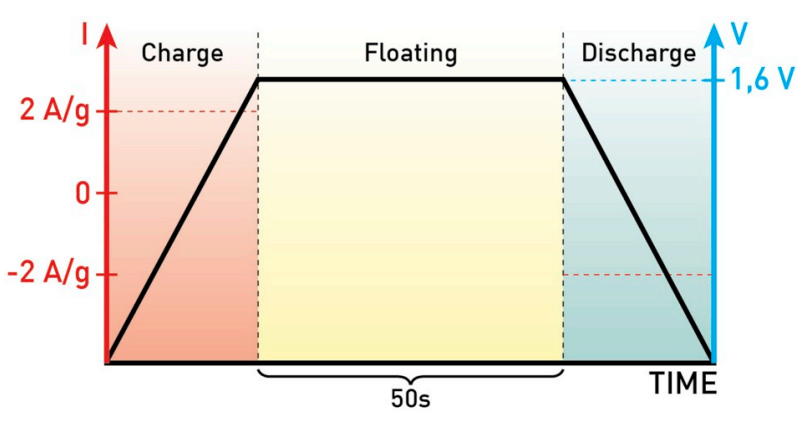

Fig. 3. Typical cycle of stability that includes combined G-CD at $\pm 2 \mathrm{Ag}^{-1}$ with potentiostatic floating at $1.6 \mathrm{~V}$ during $50 \mathrm{~s}$.

monitored by different control tests ( $\mathrm{CV}$ at $5 \mathrm{mV} \mathrm{s}{ }^{-1}, \mathrm{G}-\mathrm{CD}$ at $0.2 \mathrm{Ag}^{-1}$ and EIS) carried out at intermediate number of cycles (e.g. $0,2 \mathrm{k}, 5 \mathrm{k}$, etc.) as provided in Figs. 4 and 5.

The initial voltammograms exhibit rectangular shapes especially in Cotton@Nafion SC, while the Cotton@Aquivion SC shows higher resistive effects, and as far as the number of cycles are progressing (Fig. 4a and c) deviations from these initial behaviours are observed. For instance, a broad hump above $5 \mathrm{k}$ cycles during charge and discharge voltammetries is clearly manifested for Cotton@Nafion SC. On the contrary, the voltammograms of Cotton@Aquivion SC proceed more regularly and flat humps can be observed only after $10 \mathrm{k}$ cycles. Furthermore, it is possible to observe how the inversion of the sign of the
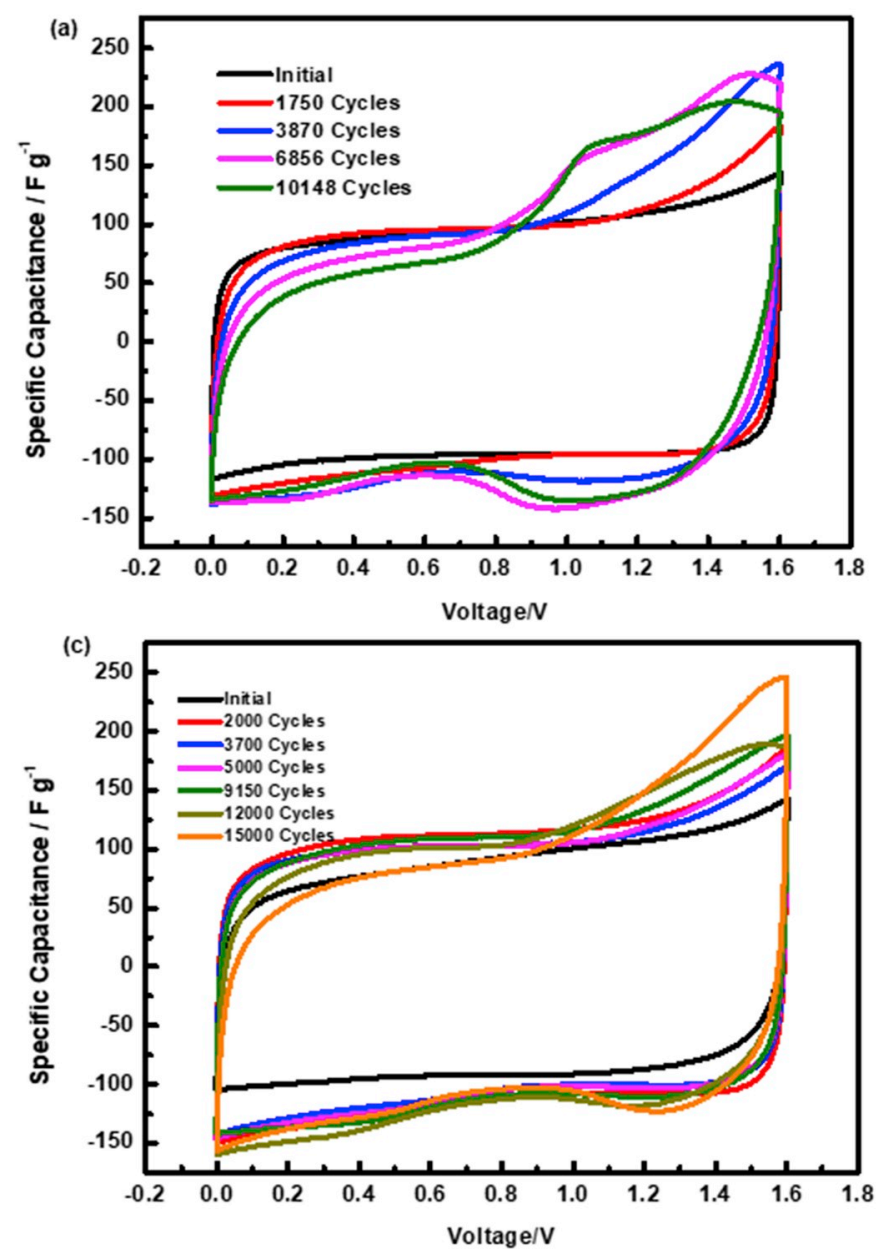

current at $1.6 \mathrm{~V}$ and $0 \mathrm{~V}$ is practically instantaneous during all voltammetries (Fig. 4a and c). This means that both SCs still show low resistance, while at the same time their capacitances increase as the number of cycles move forward, as it is observed from the negative/positive areas, which are higher than the areas of the starting cycles. In conclusion, there is not any deterioration detected from CV at high number of cycles, and the discharge time after 10 and $15 \mathrm{k}$ cycles for both SCs are also higher than initial (G-CD Fig. 4b and d). These trends and results were not expected because our supercapacitors include the $\mathrm{MnO}_{2}$ as the pseudocapacitive material in positive electrodes, and during the tests, the electrodes and electrolytes were subjected to severe conditions. We have reported similar achievements in a previous work [27], though in that work the cycles were performed with a lower stringent methodology, and consequently the results showed here on the long-term durability of this type of SCs provide a new scientific finding.

The progression of the durability tests and the state-of-health of both SCs were also monitored by in-situ EIS and their representative Nyquist and Bode plots are shown in Fig. 5. The Nyquist plots of both SCs at high frequencies ( $\mathrm{kHz}$ range), described in the insets of Fig. 5a and c, demonstrate a small increase in their whole resistance, which includes the electrolyte, the electrode/collectors and the electrolyte/electrodes resistances, with the progression of the cycles. In addition to the mentioned resistances, the charge transfer resistance, $\mathrm{R}_{\mathrm{CT}}$, due to the diffusion of the charges (i. e. ions and electrons) through the electrodes has also to be included in that whole resistance increase. The absence of low frequency semicircles ( $\mathrm{mHz}$ range) indicates that accentuated redox processes were not detected in both SCs even over a long time-scale of
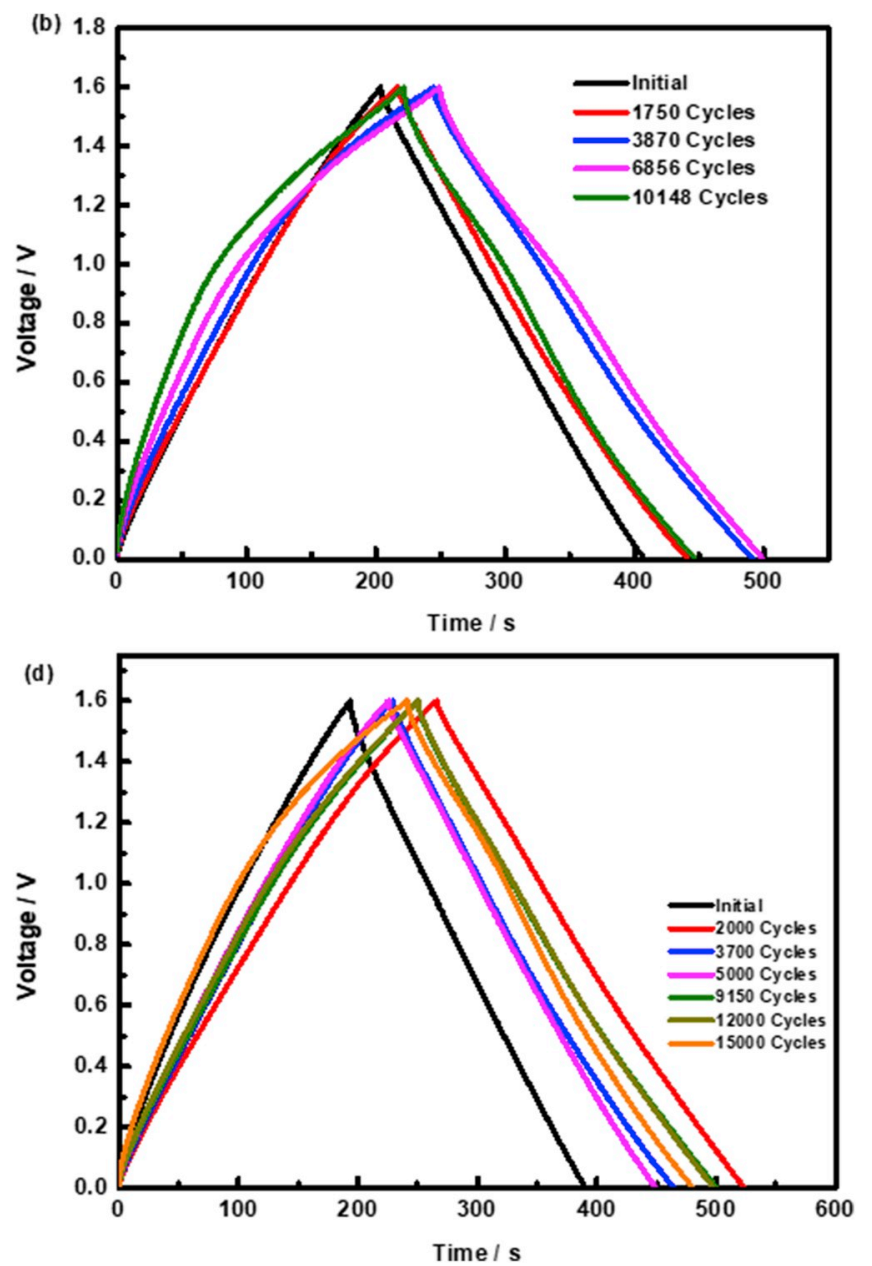

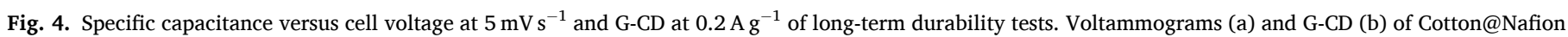
SC. Voltammograms (c) and G-CD (d) of Cotton@Aquivion SC. 

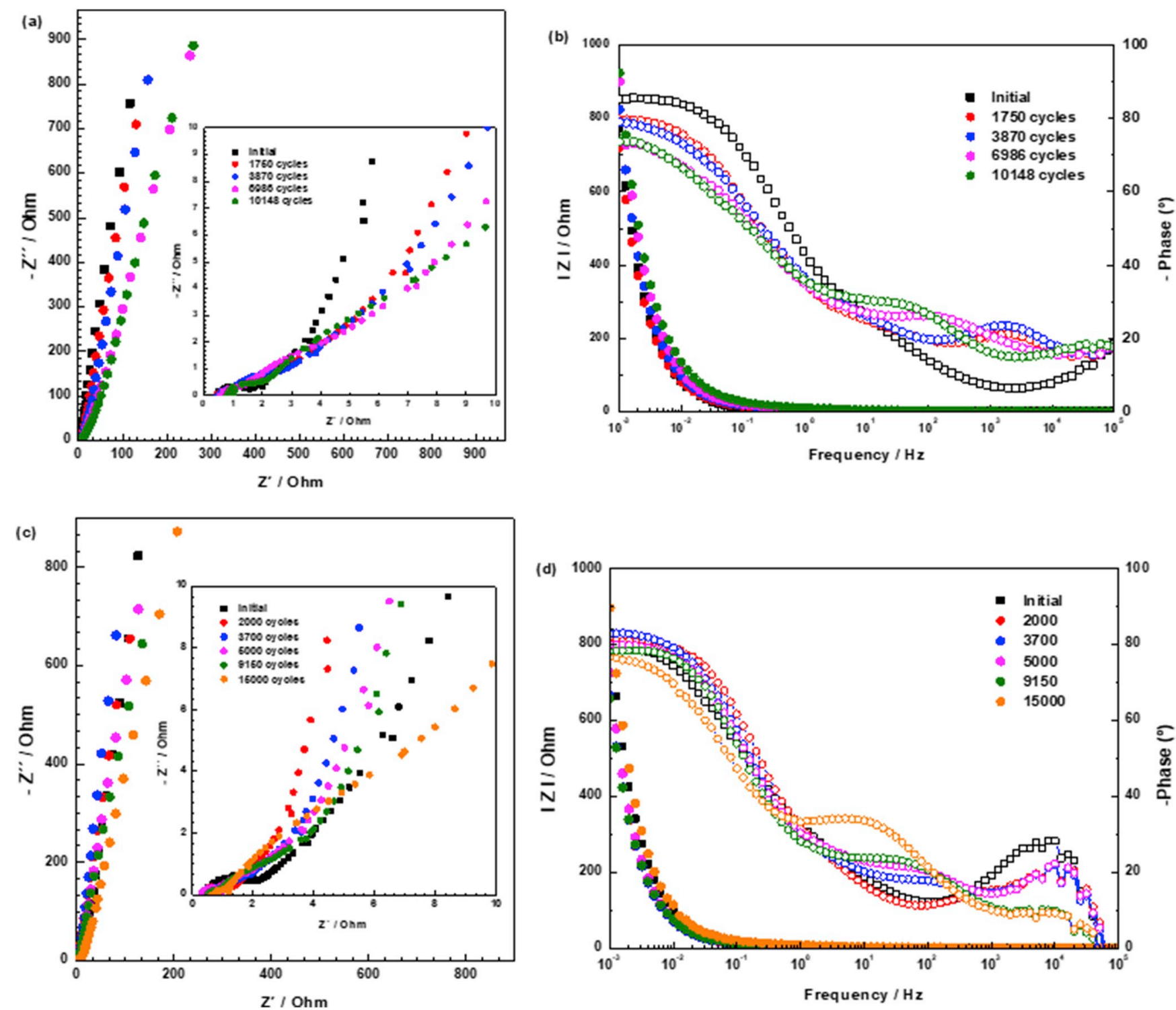

Fig. 5. Long-term durability EIS of Cotton@Nafion (top) and Cotton@Aquivion SC (bottom). Nyquist plots (the inset shows the high-frequency region) (a) and (c); Bode plots (absolute impedance is the solid symbol and the phase angle is the open symbol) (b) and (d).

measurement ( $1 \mathrm{mHz}$ is equivalent to $1000 \mathrm{~s})$. Furthermore, the data points almost vertically situated on the left part of Nyquist plots (Fig. 5 a and c) show that both cells behave as quasi-ideal capacitors with a slight frequency dependence caused by the increase of $\mathrm{R}_{\mathrm{CT}}$ during the progression of cycles. The Bode plots of SC at the initial condition (Fig. 5b and d) show that both cells resemble quasi-ideal capacitors with phaseshift angles very close to $-90^{\circ}$ (i. e. ideal EDLC behaviour) and then, as the number of cycles is increasing, the phase-shift angles decrease up to about $-75^{\circ}$ with a behaviour closer to a pseudocapacitor [42]. It must be reminded that a phase-angle of $-80^{\circ}$ was proposed as an indicator to distinguish a capacitor from a non-capacitor like behaviour [42,43], though this statement has not gained a general consensus. Taking that indicator into consideration, our study shows a change from an ideal EDLC to pseudocapacitor (Fig. 5b and d) as the number of cycles runs forward. Furthermore, a broadening of the phase peaks from higher to lower frequencies, particularly in the Cotton@Aquivion SC, is observed with the increase of number of cycles. These modifications may be associated with the appearance of some slower redox process in $\mathrm{MnO}_{2}$ based electrodes, which have also been detected in the voltammograms of both SCs (Fig. 4a and c). In summary, both SCs showed good capacitive behaviour and high electrochemical performance despite the cells were subjected to very stressful ageing conditions. For instance, the Cotton@Nafion SC was subjected to 10 k G-CD cycles, which includes a potentiostatic floating phase of approximately $140 \mathrm{~h}$ at $1.6 \mathrm{~V}$. These are exceptional results if we consider that low-cost materials such as AC, $\mathrm{MnO}_{2}$ and electrical insulating cotton woven fabric were utilized in the production of the electrodes.

The morphology of aged electrodes was analyzed by SEM to further investigate the effects of accelerated ageing tests and it is shown in Fig. 6. The electrodes were just dried, without any type of washing, in order to avoid any undesired alteration of the samples before the SEM analysis. Fig. 6a and c show evident white large particles of deposited $\mathrm{Na}_{2} \mathrm{SO}_{4}$ salt electrolyte and they do not show clearly any particle growth corresponding to $\mathrm{MnO}_{2}$. The Fig. 6a shows also some effect of fusing or coarsening among $\mathrm{MnO}_{2}$ particles corresponding to the positive electrodes of Cotton@Nafion SC, though they remained in the nanometric range. A flattening effect caused by the pression of the electrodes against the membranes in the cell, that slightly alters their morphology, can be clearly observed in the disassembled aged positive electrodes, when compared with the fresh ones (Fig. 1a). Apart from that, the SEM images of the fresh and the aged positive and negative electrodes of both SC do not show any significant change in their morphological appearance. 

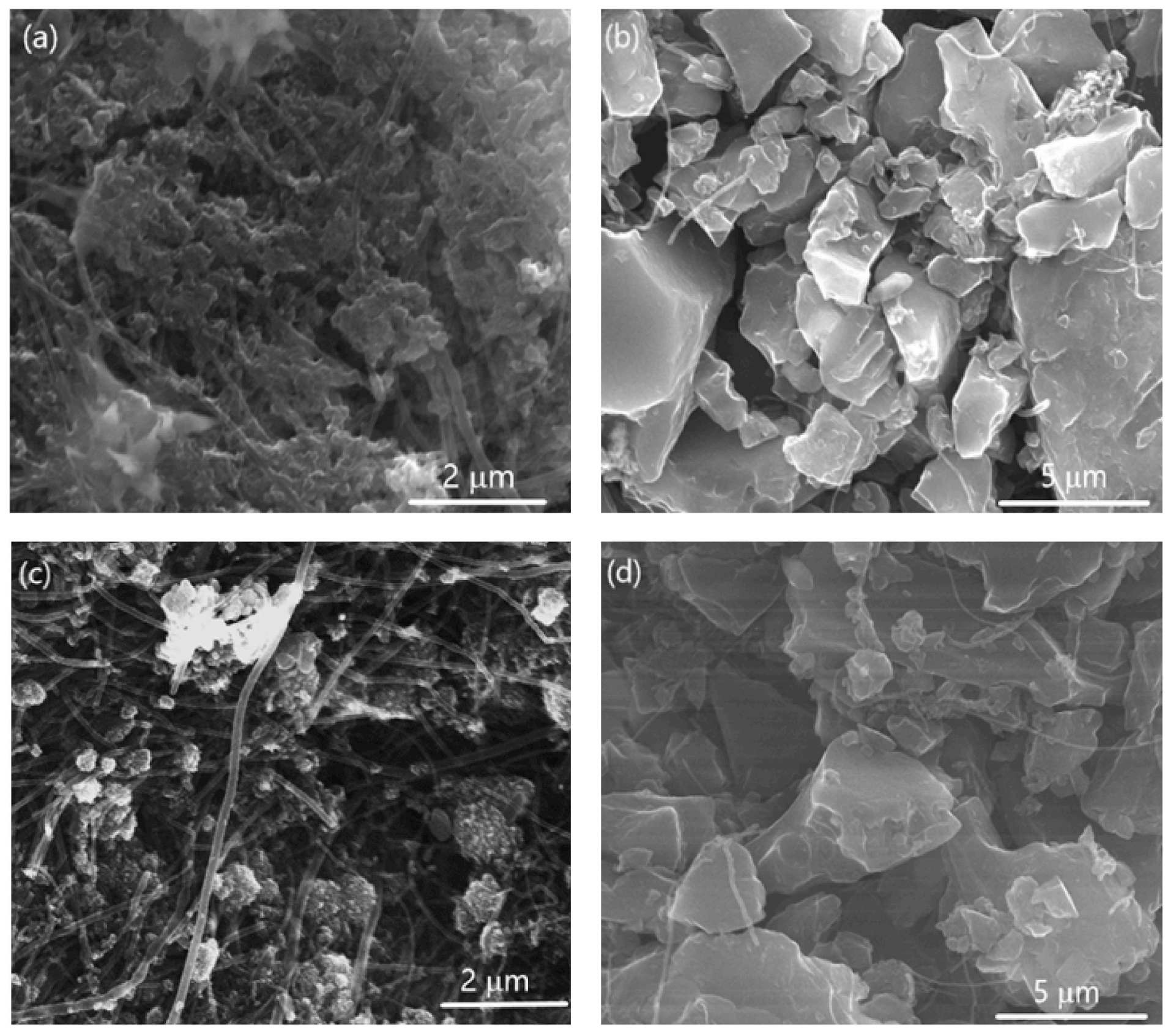

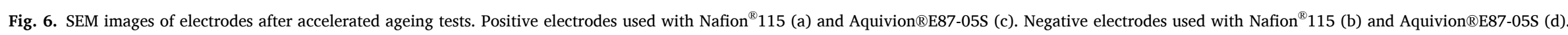


The x-ray photoelectron spectroscopy was also performed to evaluate the surface chemical composition of the positive and negative electrodes after ageing tests and the results are shown in Fig. 7 and Table 2. Fig. 7a and b clearly show the presence of deposited $\mathrm{Na}_{2} \mathrm{SO}_{4}$ salts on the surface of both positive and negative aged electrodes. The negative aged electrodes (Fig. 7a) present $\mathrm{C}$ 1s and $\mathrm{F}$ 1s peaks derived from the activated carbon and PVDF binder, respectively, whereas $\mathrm{Na}$ $1 \mathrm{~s}, \mathrm{~S} 2 \mathrm{~s}$ and $\mathrm{O} 1 \mathrm{~s}$ peaks come from the sodium sulphate of the electrolyte. In addition, some traces of titanium oxide ( $\mathrm{Ti} 2 \mathrm{p}_{3 / 2}$ ) and silica (Si $2 \mathrm{~s}$ ) were also evidenced. The silica traces may come from some contamination present in the cell, while $\mathrm{TiO}_{2}$ is likely due to a slight corrosion from the titanium cell plates. A similar consideration can be done for the positive aged electrodes (Fig. $7 \mathrm{~b}$ ), where the same chemical compounds together with the manganese oxides are observed. The F, Na, S elements were not further analysed at high resolution because they are not electrochemically active materials in the operating voltage of both SCs. On the other hand, although the oxygen is present in $\mathrm{MnO}_{\mathrm{x}}$, the $\mathrm{O}$ 1s spectra was also not further considered in this discussion because of the oxygen contribution occurs from multiple sources such as $\mathrm{MnO}_{2}, \mathrm{Na}_{2} \mathrm{SO}_{4}, \mathrm{H}_{2} \mathrm{O}$, and the presence of oxygen-based functional groups on the carbon surfaces of $\mathrm{CB}, \mathrm{CNF}$, and the cotton textile used. Consequently, Mn $2 \mathrm{p}_{3 / 2}$ spectra were used to distinguish the main states of manganese oxidation (i. e. $\mathrm{Mn}^{4+}, \mathrm{Mn}^{3+}$ and $\mathrm{Mn}^{2+}$ ) and discern the presence of the three major components $\mathrm{MnO}_{2}, \mathrm{MnOOH} / \mathrm{MnOONa}$ and $\mathrm{MnO}$ in the fresh (Fig. 7c) and aged positive electrodes used with Nafion ${ }^{\circledR} 115$ (Fig. 7d) and Aquivion ${ }^{\circledR} E 87-05 S$ (Fig. 7e) membranes. Overall, multiple peaks are assigned to the different oxidation states of manganese oxide [27], though $\mathrm{Mn}^{3+}$ and $\mathrm{Mn}^{4+}$ species have to be added to the main peaks because they arise from the multiplet-splitting components of Mn $2 p$ (IV) when an atom contains unpaired d electrons [44,45]. The main peak of manganese oxide appears at the binding energy of $642.8 \pm 0.4 \mathrm{eV}$, which corresponds to $\mathrm{MnO}_{2}$ (IV). Other two peaks with values of $641 \pm 0.4 \mathrm{eV} \quad\left(\mathrm{Mn}^{2+}\right)$ and $642 \pm 0.4 \mathrm{eV}$ for $\mathrm{Mn}^{3+}$ (MnOOH/MnOONa) were also found. Significantly, there were not observed any evident signs of degradation in the manganese oxide based electrodes from the comparison of the three high resolution $\mathrm{Mn} 2 \mathrm{p}_{3 / 2}$ spectra (Fig. 7c-e) and the survey analysis (Fig. 7b) for aged (Fig. $7 \mathrm{~d}$ and e) and fresh samples (Fig. 7c), despite they were subjected to very stressful electrochemical tests for about 2-3 months. Moreover, the simultaneous co-existence of $\mathrm{Mn}^{4+}, \mathrm{Mn}^{3+}$ and $\mathrm{Mn}^{2+}$ metal oxides, clearly confirms that these electrodes were not significantly altered after the prolonged tests. It must be reminded that the possible fast surface redox reactions produced in our $\mathrm{MnO}_{2}$-based positive electrodes can be ascribed to reversible surface electrochemical reactions associated with adsorption/desorption of alkali metal cations such as $\mathrm{Na}^{+}$and protons $\mathrm{H}^{+}$[46], described by the following equation where $\mathrm{C}+=\mathrm{Na}^{+}, \mathrm{H}^{+}, \mathrm{K}^{+}$: (a)

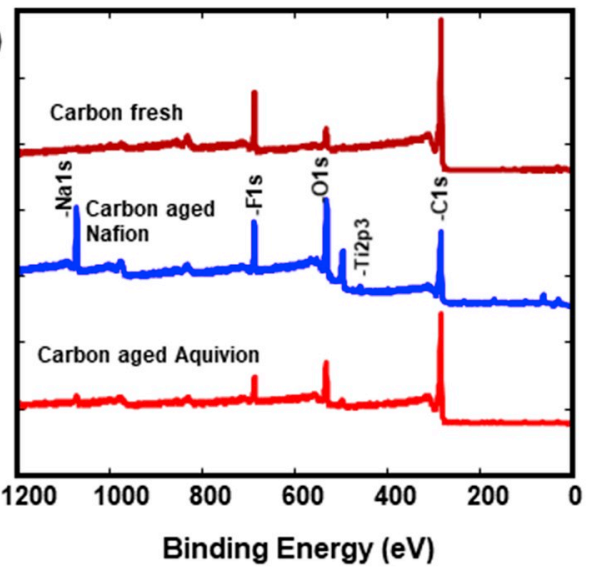

(b)

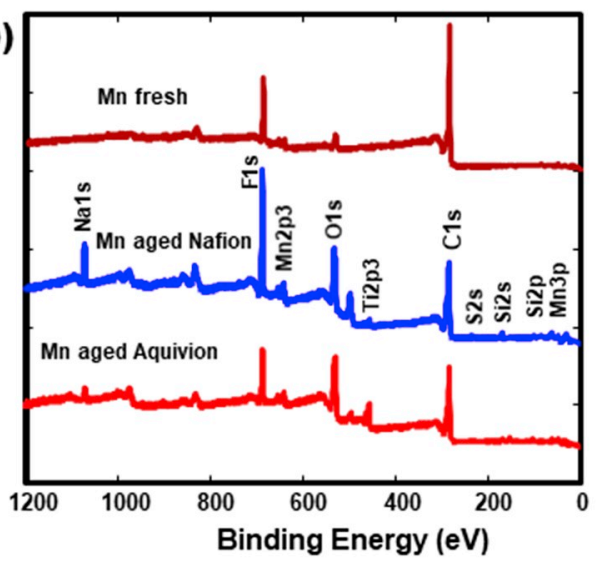

(c)

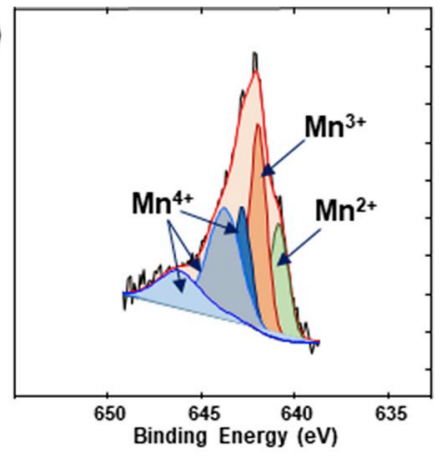

(d)

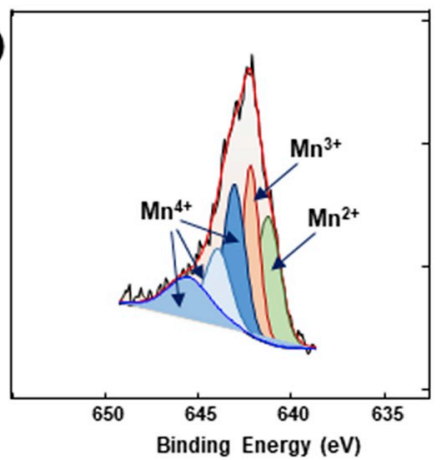

(e)

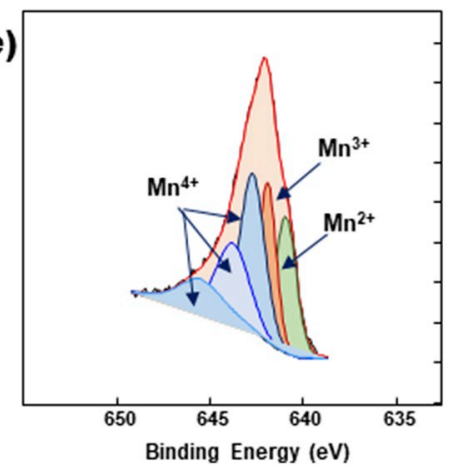

Fig. 7. XPS survey and deconvolution plots of fresh and aged electrodes. XPS of negative (a) and positive electrodes (b). Deconvolution of $\mathrm{Mn}_{2} 2 \mathrm{p}_{3 / 2}$ for $\mathrm{MnO}_{\mathrm{x}}$-fresh electrode (c), $\mathrm{MnO}_{\mathrm{x}}$ aged $\mathrm{Nafion}^{\circledR} 115$ electrode (d), and $\mathrm{MnO}_{\mathrm{x}}$ aged Aquivion ${ }^{\circledR} \mathrm{E} 87-05 S$ electrode (e). 
Table 2

XPS results of Mn 2 $\mathrm{p}_{3 / 2}$ spectral fitting parameters: binding energy (eV) and percentage of total area for the fresh and aged electrodes.

\begin{tabular}{|c|c|c|c|c|c|}
\hline \multirow{2}{*}{$\frac{\text { Electrodes }}{\text { Peak }}$} & \multicolumn{5}{|c|}{ Mn 2p3/2 } \\
\hline & Peakl & Peak 2 & Peak 3 & Peak $4^{\mathrm{a}}$ & Peak $5^{\mathrm{a}}$ \\
\hline $\mathrm{BE}(\mathrm{eV})$ compounds (valence) & $641 \pm 0.4 \mathrm{MnO}$ (II) & $641 \pm 0.4 \mathrm{MnOOH} \mathrm{MnOONa}$ (III) & $642.8 \pm 0.4 \mathrm{MnO}_{2}$ (IV) & $643.8 \pm 0.4 \mathrm{MnO}_{2}(\mathrm{IV})$ & $645.5 \pm 0.4 \mathrm{MnO}_{2}$ (IV) \\
\hline Mn oxide fresh (\%) & 17.47 & 27.82 & 15.63 & 27.92 & 11.14 \\
\hline Mn oxide aged & 22.84 & 21.10 & 29.24 & 17.87 & 8.95 \\
\hline \multicolumn{6}{|l|}{ Cotton@Nafion (\%) } \\
\hline Mn oxide aged & 25.49 & 23.49 & 24.18 & 14.41 & 12.33 \\
\hline Cotton@Aquivion (\%) & & & & & \\
\hline
\end{tabular}

${ }^{\text {a }}$ (Additional peaks are due to binding energy shifts and attributed to multiplet splitting structures).

$\mathrm{MnO}_{2}+\mathrm{xC}^{+}+\mathrm{yH}^{+}+(\mathrm{x}+\mathrm{y}) \mathrm{e}^{-} \leftrightarrow \mathrm{MnOOC}_{\mathrm{x}} \mathrm{H}_{\mathrm{y}}$

This electrode mechanism, which involves a reversible redox reaction between IV and III Mn oxidation states, becomes more evident in the voltammograms of Fig. $4 \mathrm{a}$ and $\mathrm{c}$ with the appearance of humps with some deviation from rectangular shapes. This deviation is probably caused by the increased insertion of ions under the floating condition at the maximum voltage of $1.6 \mathrm{~V}$, which could promote a higher electroinsertion of cations in the inner parts of the Mn electrodes.

In summary, the preserved morphology of the aged electrodes observed by the SEM images and the excellent electrochemical performance, demonstrate the lack of significant changes in both SCs. In this regard, a slight increase in their performance after $10 \mathrm{k}$ and $15 \mathrm{k}$ cycles and $140 \mathrm{~h}$ and $210 \mathrm{~h}$ of potentiostatic floating conditions at $1.6 \mathrm{~V}$ was observed, in contrast with the current state-of-art, which normally reports a performance decay after a few hundred (or thousands) of fast charge and discharge cycles [47-49].

The very significant results of our developed hybrid solid-state SC are also shown in the comparative plots of Fig. 8. The Cotton@Nafion SC worked perfectly for $10 \mathrm{k}$ cycles and $140 \mathrm{~h}$ of potentiostatic floating at $1.6 \mathrm{~V}$, after which the test was deliberately stopped, while the Cotto$\mathrm{n} @$ Aquivion SC was subjected for $15 \mathrm{k}$ cycles and $210 \mathrm{~h}$ of potentiostatic floating at $1.6 \mathrm{~V}$ before ending deliberately the test (Fig. 8a). The specific capacitances of both capacitors, obtained from the G-CD at $0.2 \mathrm{~A} \mathrm{~g}^{-1}$ for different number of cycles, started from values of about $105 \mathrm{~F} \mathrm{~g}^{-1}$ and then they increased until values of about $130 \mathrm{Fg}^{-1}$. Thereafter, the capacitances remained constant and without any appreciable decay over that initial value until the end of the durability measurements, as it is evidenced by the solid lines in Fig. 8a. Furthermore, there was not observed any evident deterioration due to the corrosion phenomena in the current collector made of almost pure titanium (99.8\%), normally observed in the positive current collector of SCs based on aqueous electrolytes [50,51]. In conclusion, our developed SCs work efficiently in neutral aqueous systems without any appreciable decay effects, despite the very harsh conditions to which electrodes, electrolytes and current collectors were subjected.

The Fig. $8 \mathrm{~b}$ reports the voltage decay in the self-discharge behavior after $4 \mathrm{~h}$ of charging at constant voltage of $1.6 \mathrm{~V}$ of both aged SCs for 10 $\mathrm{k}$ cycles. This decrease of cell voltage can be caused by charge redistribution and various parasitic redox processes due to the presence of inorganic or organic impurities in the electrodes, which can produce undesired parallel chemical reactions, mass transport limitations and additional ohmic resistances [52-54]. In any case and despite the self-discharge rate is not completely eliminated in our SCs, it is small enough to be considered as negligible for practical devices.

The comparison of the electrochemical performance of SCs developed in this study with other supercapacitors based on textile-based electrodes reported in literature is summarized in Table 3 . In our study, the highest specific capacitance of $132 \mathrm{Fg}^{-1}$ at $0.2 \mathrm{Ag}^{-1}$ was achieved with the Cotton@Nafion SC that showed an ionic resistance of $0.78 \Omega \mathrm{cm}^{2}$, and an energy density of $11.55 \mathrm{Wh} \mathrm{kg}^{-1}$. Our results are already remarkable when compared to similar asymmetric SCs reported in Table 3. Furthermore, they have shown low self-discharge rates and very good long-term durability under harsh cycling conditions, which are distinctive points of strength compared to the state-of-art for the design of future advanced solid-state SCs in neutral aqueous environments at operating voltages up to $1.6 \mathrm{~V}$.

\section{Conclusions}

Two type of hybrid solid-state supercapacitors based on cotton fabric
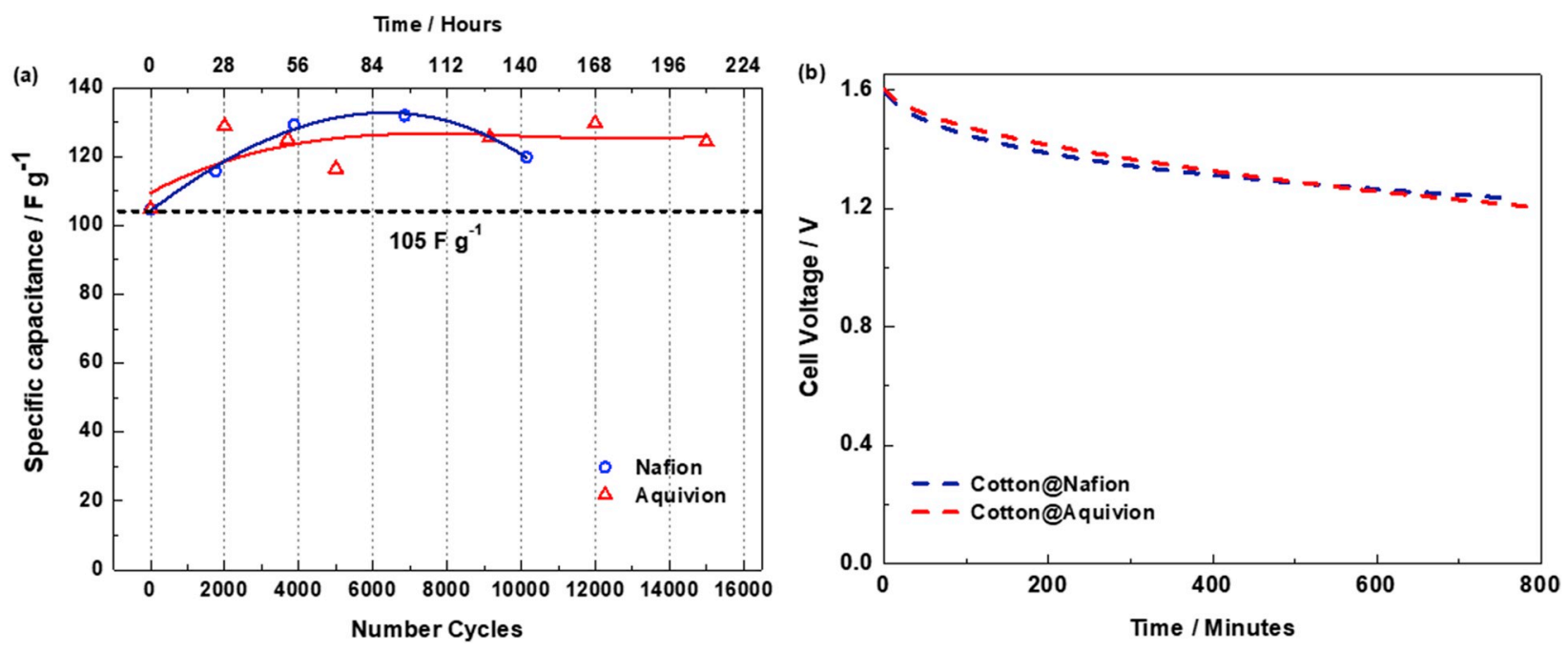

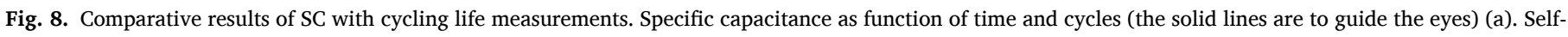
discharge rate after charging the SC for $4 \mathrm{~h}$ at $1.6 \mathrm{~V}$ (b). 
Table 3

Performance comparative table of supercapacitors developed in this study with other Symmetric (S) and Asymmetric (A) flexible SC.

\begin{tabular}{|c|c|c|c|c|c|c|c|c|c|}
\hline $\begin{array}{l}\text { SC } \\
\text { type }\end{array}$ & Substrate & Active materials & Electrolyte & Separator & $\begin{array}{c}\text { Working } \\
\text { voltage (V) }\end{array}$ & $\begin{array}{l}\text { Capacitance (F } \\
\left.\mathrm{g}^{-1}\right) \text { at current }\end{array}$ & $\begin{array}{l}\text { Energy density } \\
\quad\left(\mathrm{Wh} \mathrm{kg}^{-1}\right)\end{array}$ & Retention & Refs \\
\hline S & Cotton Fabric & SWCNT, $\mathrm{MnO}_{2}$ & $2 \mathrm{M} \mathrm{Li}_{2} \mathrm{SO}_{4}$ & $\begin{array}{l}\text { Cotton } \\
\text { Fabric }\end{array}$ & 0.8 & $1701 \mathrm{~mA} / \mathrm{cm}^{2}$ & - & $100 \% 35$ K Cycles & [17] \\
\hline $\mathrm{S}$ & Cotton Fabric & GO & $\begin{array}{l}2 \mathrm{M} \mathrm{EMIMBF}_{4} / \\
\text { acetonitrile }\end{array}$ & $\begin{array}{l}\text { Cotton } \\
\text { Fabric }\end{array}$ & 2 & $\begin{array}{c}18.3 \\
0.1 \mathrm{~A} / \mathrm{g}\end{array}$ & 12.3 & $93 \% 1.5$ K Cycles & [6] \\
\hline A & Carbon Fabric & $\mathrm{MnO}_{2}, \mathrm{Fe}_{2} \mathrm{O}_{3}$ & PVA/LiCl & - & 1.6 & $\begin{array}{c}91.3 \\
2 \mathrm{~mA} / \mathrm{cm}^{2}\end{array}$ & 32.5 & "Good" 5 K Cycles & [23] \\
\hline$S$ & Cotton Fabric & Ni, MWCNT, rGO & $5 \mathrm{M} \mathrm{LiCl}$ & $\begin{array}{l}\text { Cotton } \\
\text { Fabric }\end{array}$ & 0.8 & $\begin{array}{c}262 \\
0.84 \mathrm{~A} / \mathrm{g}\end{array}$ & - & $118 \% 10$ K Cycles & [19] \\
\hline S & Cotton Fabric & $\begin{array}{l}\text { Activated Carbon } \\
\text { (AC) }\end{array}$ & $1 \mathrm{M} \mathrm{Li}_{2} \mathrm{SO}_{4}$ & $\begin{array}{c}\text { PTFE } \\
\text { membrane }\end{array}$ & 1 & $\begin{array}{c}90 \\
0.25 \mathrm{~A} / \mathrm{g}\end{array}$ & - & 92\% 10K Cycles & [55] \\
\hline$S$ & Cotton Fabric & PPy & $2 \mathrm{M} \mathrm{NaCl}$ & - & 0.8 & $\begin{array}{c}325 \\
1 \mathrm{~A} / \mathrm{g}\end{array}$ & 24.7 & 63\% 500 Cycles & [18] \\
\hline A & $\begin{array}{c}\text { Activated } \\
\text { Cotton Textile } \\
\text { (ACT) }\end{array}$ & ACT, $\mathrm{MnO}_{2}$ & $1 \mathrm{M} \mathrm{Na}_{2} \mathrm{SO}_{4}$ & $\begin{array}{l}\text { Whatman } \\
\text { Paper }\end{array}$ & 2 & $1201 \mathrm{~mA} / \mathrm{cm}^{2}$ & $16.7^{\mathrm{a}}$ & 97.5\% 1K Cycles & [13] \\
\hline A & ACT & $\mathrm{NiCo}_{2} \mathrm{O}_{4}, \mathrm{NiCo}_{2} \mathrm{O}$ & $\mathrm{PVA} / \mathrm{KOH}$ & - & 1.6 & $\begin{array}{c}60 \\
100 \mathrm{~mA} / \mathrm{cm}^{2}\end{array}$ & $21.3^{\mathrm{a}}$ & 100\% 1K Cycles & [14] \\
\hline A & $\begin{array}{l}\text { Carbon Cloth } \\
\text { (CC) }\end{array}$ & $\mathrm{MnO}_{2}, \mathrm{CC}$ & PVA/LiCl & - & 2.0 & $\begin{array}{c}178 \\
4 \mathrm{~mA} / \mathrm{cm}^{2}\end{array}$ & 25 & 96\% 20 K Cycles & [56] \\
\hline A & $\begin{array}{l}\text { Carbon } \\
\text { Nanofiber } \\
\text { Paper }\end{array}$ & $\mathrm{MnO}_{2}, \mathrm{Bi}_{2} \mathrm{O}_{3}$ & $1 \mathrm{M} \mathrm{Na}_{2} \mathrm{SO}_{4}$ & Filter Paper & 1.8 & $\begin{array}{c}100.8 \\
1.5 \mathrm{~mA} / \mathrm{cm}^{2}\end{array}$ & 11.3 & $\begin{array}{c}85 \% \\
4 \text { K Cycles }\end{array}$ & [20] \\
\hline$S$ & Carbon Cloth & $\begin{array}{l}\text { MultiScale Porous } \\
\text { Carbon }\end{array}$ & $\begin{array}{c}0.5 \mathrm{M} \mathrm{H}_{2} \mathrm{SO}_{4}, \\
1 \mathrm{M} \mathrm{KOH}\end{array}$ & $\begin{array}{l}\text { Porous } \\
\text { Paper }\end{array}$ & 1.4 & $\begin{array}{c}177 \mathrm{mF} / \mathrm{cm}^{2} \\
1 \mathrm{~mA} / \mathrm{cm}^{2}\end{array}$ & $\begin{array}{c}0.72 \mathrm{mWh} / \\
\mathrm{cm}^{3}\end{array}$ & $\begin{array}{c}85 \% \\
30 \text { K Cycles }\end{array}$ & [3] \\
\hline $\mathrm{S}$ & $\begin{array}{c}\text { Flexible } \\
\text { Stainless-Steel }\end{array}$ & $\mathrm{AC}$ & $1 \mathrm{M} \mathrm{Li}_{2} \mathrm{SO}_{4}$ & $\begin{array}{c}\mathrm{Li}_{2} \mathrm{SO}_{4} \\
\mathrm{Gel} \\
\text { Electrolyte }\end{array}$ & 2.1 & - & 26.5 & $\begin{array}{c}94 \% \\
10 \text { K Cycles }\end{array}$ & [57] \\
\hline A & $\begin{array}{l}\text { Nickel Foam, } \\
\text { Carbon Cloth }\end{array}$ & NiO, NiOOH, PPy & $4 \mathrm{M} \mathrm{KOH}$ & Filter Paper & 1.4 & $0.613 \mathrm{mAh} / \mathrm{cm}^{2}$ & $\begin{array}{c}4.12 \mathrm{mWh} / \\
\mathrm{cm}^{3}\end{array}$ & $\begin{array}{c}88 \% \\
5 \text { K Cycles }\end{array}$ & [58] \\
\hline A & Carbon Cloth & $\mathrm{rGO}, \mathrm{MnO}_{2}$ & $\mathrm{PVA} / \mathrm{Na}_{2} \mathrm{SO}_{4}$ & - & 2 & $120 \mathrm{mF} / \mathrm{cm}^{2}$ & $64 \mu \mathrm{Wh} / \mathrm{cm}^{3}$ & $\begin{array}{c}95 \% \\
10 \text { K Cycles }\end{array}$ & [5] \\
\hline $\mathrm{S}$ & Graphite Paper & $\mathrm{MnO}_{2}$ & $1 \mathrm{M} \mathrm{Na}_{2} \mathrm{SO}_{4}$ & $\begin{array}{c}\text { Porous } \\
\text { Paper }\end{array}$ & 1 & $\begin{array}{c}76.1 \mathrm{mF} / \mathrm{cm}^{3} \\
0.5 \mathrm{~mA} / \mathrm{cm}^{2}\end{array}$ & $\begin{array}{c}10.6 \mathrm{mWh} / \\
\mathrm{cm}^{3}\end{array}$ & $\begin{array}{c}93.6 \% \\
1 \text { K Cycles }\end{array}$ & [59] \\
\hline$S$ & - & 3D rGO & $\mathrm{PVA} / \mathrm{H}_{3} \mathrm{PO}_{4}$ & - & 1 & $\begin{array}{c}81 \\
0.5 \mathrm{~A} / \mathrm{g}\end{array}$ & 11.5 & $\begin{array}{c}94.5 \% \\
1 \text { K Cycles }\end{array}$ & [60] \\
\hline$S$ & $\begin{array}{l}\text { Polyester } \\
\text { Textile }\end{array}$ & rGO, PANI & $\mathrm{PVA} / \mathrm{H}_{3} \mathrm{PO}_{4}$ & - & 0.8 & $\begin{array}{c}152 \\
0.5 \mathrm{~mA} / \mathrm{cm}^{2}\end{array}$ & - & $\begin{array}{c}85.9 \% \\
1 \text { K Cycles }\end{array}$ & [19] \\
\hline A & Cotton textile & $\mathrm{CNF}+\mathrm{AC}+\mathrm{MnO}_{2}$ & $\begin{array}{c}\text { Nafion- } \mathrm{Na}^{+} / 1 \mathrm{M} \\
\mathrm{Na}_{2} \mathrm{SO}_{4}\end{array}$ & Nafion & 1.6 & $132 @ 0.5$ A/g & 11.7 & $\begin{array}{c}126 \% 10 \mathrm{~K} \\
\text { cycles }+(140 \mathrm{~h} @ \\
1.6 \mathrm{~V})\end{array}$ & $\begin{array}{l}\text { This } \\
\text { work }\end{array}$ \\
\hline A & Cotton textile & $\mathrm{CNF}+\mathrm{AC}+\mathrm{MnO}_{2}$ & $\begin{array}{l}\text { Aquivion- } \mathrm{Na}^{+} / \\
1 \mathrm{M} \mathrm{Na}_{2} \mathrm{SO}_{4}\end{array}$ & aquivion & 1.6 & $130 @ 0.2 \mathrm{~A} / \mathrm{g}$ & 11.55 & $\begin{array}{c}125 \% 15 \mathrm{~K} \\
\text { cycles }+(210 \mathrm{~h}- \\
1.6 \mathrm{~V})\end{array}$ & $\begin{array}{l}\text { This } \\
\text { work }\end{array}$ \\
\hline
\end{tabular}

${ }^{\text {a }}$ Energy density is derived from capacitance of a single electrode

electrodes were designed and analysed in this work. One SC was assembled with Nafion ${ }^{\circledR} 115$ and the other SC with Aquivion ${ }^{\circledR}$ E87-05S polymer electrolyte. Furthermore, a new lifetime assessment methodology, consisting of the combination of galvanostatic charge/discharge and potentiostatic floating tests, was designed and carried out for the first time in order to get insight on the durability of both SCs under harsh test environments. The voltammograms and charge-discharge profiles (at initial conditions) of the two different SC showed the typical rectangular-shape voltammetries and symmetric triangular shapes G-CD curves of quasi-ideal electric double layer capacitors with very interesting capacitive performances $\left(\approx 105 \mathrm{~F} \mathrm{~g}^{-1}\right)$ in neutral aqueous environment at cell voltage of $1.6 \mathrm{~V}$, which are comparable to similar results found in literature but with the difference that our SCs were produced with very simple and scalable methods and a majority of low-cost materials such as cotton fabric, activated carbon, carbon black and $\mathrm{MnO}_{2}$ nanoparticles. The designed SCs showed very low self-discharge rates and even an increase in their capacitances of 25\% (from 105 to $132 \mathrm{~F} \mathrm{~g}^{-1}$ ) during long-term durability tests. In particular, the SC based on Nafion ${ }^{\circledR} 115$ membrane was subjected to the potentiostatic floating condition of $1.6 \mathrm{~V}$ for more than $10 \mathrm{~K}$ cycles and $140 \mathrm{~h}$, whereas the SC based on Aquivion ${ }^{\circledR}$ E87-05S membrane achieved $15 \mathrm{k}$ cycles and $210 \mathrm{~h}$ at $1.6 \mathrm{~V}$ in perfect operation. The post-mortem analysis (e.g. SEM and XPS) made on the fresh and aged electrodes did not show significant structural changes in their morphologies, which means that the $\mathrm{MnO}_{2}$ nanoparticles and activated carbon utilized were not degraded, despite they have been subjected to very stringent testing conditions.

\section{Conflicts of interest}

The authors declare no conflict of interest.

\section{Acknowledgments}

This work was supported by Project UID/CTM/00264/2019 of 2C2T - Centro de Ciência e Tecnologia Têxtil, funded by National Founds through FCT/MCTES. This research was also partially supported by the Cost Action 15107, Grant No. ECOST-STSM-CA15107-300118-092731. The authors acknowledge Mr. A. Brigandì (CNR-ITAE) and Mr. G. Monforte for their help with electrochemical tests and XPS analysis, respectively and Mr. André Paiva (2C2T) for the graphic design of Fig. 3.

\section{References}

[1] U. Gulzar, S. Goriparti, E. Miele, T. Li, G. Maidecchi, A. Toma, F. De Angelis, C. Capiglia, R.P. Zaccaria, J. Mater. Chem. 4 (2016) 16771-16800.

[2] P. Simon, Y. Gogotsi, Nat. Mater. 7 (2008) 845-854.

[3] M. Yu, D. Lin, H. Feng, Y. Zeng, Y. Tong, X. Lu, Angew. Chem. Int. Ed. 56 (2017) 5454-5459. 
[4] S. Kumar, M. Nehra, D. Kedia, N. Dilbaghi, K. Tankeshwar, K.H. Kim, Prog. Energy Combust. Sci. 64 (2018) 219-253.

[5] H. Jeon, J.M. Jeong, S.B. Hong, M. Yang, J. Park, D.H. Kim, S.Y. Hwang, B.G. Choi, Electrochim. Acta 280 (2018) 9-16.

[6] W.W. Liu, X.B. Yan, J.W. Lang, C. Peng, Q.J. Xue, J. Mater. Chem. 22 (2012) $17245-17253$.

[7] X. Guo, S. Zheng, G. Zhang, X. Xiao, X. Li, Y. Xu, H. Xue, H. Pang, Energy Storage Mater. 9 (2017) 150-169.

[8] X. Chen, R. Paul, L. Dai, Natl. Sci. Rev. 4 (2017) 453-489.

[9] Q. Meng, K. Cai, Y. Chen, L. Chen, Nano Energy 36 (2017) 268-285.

[10] B.E. Conway, W.G. Pell, J. Solid State Electrochem. 7 (2003) 637-644.

[11] M. Meller, J. Menzel, K. Fic, D. Gastol, E. Frackowiak, Solid State Ionics 265 (2014) 61-67.

[12] T.H. Wu, D. Hesp, V. Dhanak, C. Collins, F. Braga, L.J. Hardwick, C.C. Hu, J. Mater. Chem. 3 (2015) 12786-12795.

[13] L. Bao, X. Li, Adv. Mater. 24 (2012) 3246-3252.

[14] Z. Gao, N. Song, Y. Zhang, X. Li, RSC Adv. 5 (2015) 15438-15447.

[15] S. Seyedin, M.S. Romano, A.I. Minett, J.M. Razal, Sci. Rep. 5 (2015) 14946.

[16] K. Jost, D. Stenger, C.R. Perez, J.K. McDonough, K. Lian, Y. Gogotsi, G. Dion, Energy Environ. Sci. 6 (2013) 2698-2705.

[17] L. Hu, M. Pasta, F. La Mantia, L. Cui, S. Jeong, H.D. Deshazer, J.W. Choi, S.M. Han, Y. Cui, Nano Lett. 10 (2010) 708-714.

[18] J. Xu, D. Wang, L. Fan, Y. Yuan, W. Wei, R. Liu, S. Gu, W. Xu, Org. Electron.: Phys. Mater. Appl. 26 (2015) 292-299.

[19] Y. Yang, Q. Huang, L. Niu, D. Wang, C. Yan, Y. She, Z. Zheng, Adv. Mater. 29 (2017) 1606679.

[20] H. Xu, X. Hu, H. Yang, Y. Sun, C. Hu, Y. Huang, Adv. Energy Mater. 5 (2015) 7484-7539.

[21] Q. Chen, X. Li, X. Zang, Y. Cao, Y. He, P. Li, K. Wang, J. Wei, D. Wu, H. Zhu, RSC Adv. 4 (2014) 36253-36256.

[22] X. Lu, M. Yu, G. Wang, Y. Tong, Y. Li, Energy Environ. Sci. 7 (2014) 2160-2181.

[23] P. Yang, Y. Ding, Z. Lin, Z. Chen, Y. Li, P. Qiang, M. Ebrahimi, W. Mai, C.P. Wong, Z.L. Wang, Nano Lett. 14 (2014) 731-736.

[24] H. Sun, S. Xie, Y. Li, Y. Jiang, X. Sun, B. Wang, H. Peng, Adv. Mater. (2016) $8431-8438$

[25] F. Lufrano, P. Staiti, Electrochim. Acta 49 (2004) 2683-2689.

[26] F.A. Zakil, S.K. Kamarudin, S. Basri, Renew. Sustain. Energy Rev. 65 (2016) 841-852.

[27] A.J. Paleo, P. Staiti, A. Brigandì, F.N. Ferreira, A.M. Rocha, F. Lufrano, Energy Storage Mater. 12 (2018) 204-215.

[28] P. Staiti, F. Lufrano, Electrochim. Acta 55 (2010) 7436-7442.

[29] L. Zhang, Q. Chen, X. Han, Q. Zhang, J. Clust. Sci. 29 (2018) 1089-1098.

[30] E.S. Ilton, J.E. Post, P.J. Heaney, F.T. Ling, S.N. Kerisit, Appl. Surf. Sci. 366 (2016) $475-485$.

[31] I. Roger, M.A. Shipman, M.D. Symes, Nat. Rev. Chem. 1 (2017), 0003.

[32] J. Liu, D. Zhu, T. Ling, A. Vasileff, S.Z. Qiao, Nano Energy 40 (2017) 264-273.

[33] T. Brousse, D. Bélanger, J.W. Long, J. Electrochem. Soc. 162 (2015) A5185-A5189.

[34] Y. Shao, M.F. El-Kady, J. Sun, Y. Li, Q. Zhang, M. Zhu, H. Wang, B. Dunn, R. B. Kaner, Chem. Rev. 118 (2018) 9233-9280.
[35] N. Jabeen, Q. Xia, S.V. Savilov, S.M. Aldoshin, Y. Yu, H. Xia, ACS Appl. Mater. Interfaces 8 (2016) 33732-33740.

[36] G. Yu, L. Hu, N. Liu, H. Wang, M. Vosgueritchian, Y. Yang, Y. Cui, Z. Bao, Nano Lett. 11 (2011) 4438-4442.

[37] F. Lufrano, P. Staiti, Energy Fuels 24 (2010) 3313-3320.

[38] B.E. Conway, Electrochemical behavior at porous electrodes; applications to capacitors, in: B.E. Conway (Ed.), Electrochemical Supercapacitors, Springer, Boston, MA (USA), 1999, pp. 377-416.

[39] P.W. Ruch, D. Cericola, A. Foelske-Schmitz, R. Kötz, A. Wokaun, Electrochim. Acta 55 (2010) 4412-4420.

[40] D. Weingarth, H. Noh, A. Foelske-Schmitz, A. Wokaun, R. Kötz, Electrochim. Acta 103 (2013) 119-124.

[41] P. Ratajczak, K. Jurewicz, F. Béguin, J. Appl. Electrochem. 44 (2014) 475-480.

[42] T.H. Wu, Y.H. Chu, C.C. Hu, L.J. Hardwick, Electrochem. Commun. 27 (2013) 81-84.

[43] M. Rajkumar, C.T. Hsu, T.H. Wu, M.G. Chen, C.C. Hu, Prog. Nat. Sci.: Mater. Int. 25 (2015) 527-544.

[44] M.C. Biesinger, B.P. Payne, A.P. Grosvenor, L.W.M. Lau, A.R. Gerson, R.S.C. Smart, Appl. Surf. Sci. 257 (2011) 2717-2730.

[45] H.W. Nesbitt, D. Banerjee, Am. Mineral. 83 (1998) 305-315.

[46] M. Toupin, T. Brousse, D. Bélanger, Chem. Mater. 16 (2004) 3184-3190.

[47] T. Brousse, et al., Materials for electrochemical capacitors, in: C. Breitkopf, K. Swider-Lyons (Eds.), Handbook of Electrochemical Energy, Springer, Berlin, Heidelberg, 2017, pp. 495-561.

[48] W. Wei, X. Cui, W. Chen, D.G. Ivey, J. Power Sources 186 (2009) 543-550.

[49] T. Zhai, S. Xie, M. Yu, P. Fang, C. Liang, X. Lu, Y. Tong, Nano Energy 8 (2014) 255-263.

[50] P. Ratajczak, K. Jurewicz, P. Skowron, Q. Abbas, F. Béguin, Electrochim. Acta 130 (2014) 344-350.

[51] B. Evanko, S.J. Yoo, J. Lipton, S.E. Chun, M. Moskovits, X. Ji, S.W. Boettcher, G. D. Stucky, Energy Environ. Sci. 11 (2018) 2865-2875.

[52] L. García-Cruz, P. Ratajczak, J. Iniesta, V. Montiel, F. Béguin, Electrochim. Acta 202 (2016) 66-72.

[53] X. Wang, R.S. Chandrabose, S.E. Chun, T. Zhang, B. Evanko, Z. Jian, S. W. Boettcher, G.D. Stucky, X. Ji, ACS Appl. Mater. Interfaces 7 (2015) 19978-19985.

[54] H.A. Andreas, J.M. Black, A.A. Oickle, Electrochim. Acta 140 (2014) 116-124.

[55] K. Jost, C.R. Perez, J.K. McDonough, V. Presser, M. Heon, G. Dion, Y. Gogotsi, Energy Environ. Sci. 4 (2011) 5060-5067.

[56] H. Wang, C. Xu, Y. Chen, Y. Wang, Energy Storage Mater. 8 (2017) 127-133.

[57] J. Wei, J. Zhou, S. Su, J. Jiang, J. Feng, Q. Wang, ChemSusChem 11 (2018) 3410-3415.

[58] H. Khani, T.J. Dowell, D.O. Wipf, ACS Appl. Mater. Interfaces 10 (2018) 21262-21280.

[59] W. Qi, R. Lv, B. Na, H. Liu, Y. He, N. Yu, ACS Sustain. Chem. Eng. 6 (2018) 4739-4745.

[60] T. Purkait, G. Singh, D. Kumar, M. Singh, R.S. Dey, Sci. Rep. 8 (2018) 640. 